\title{
Spectrophotometric Determination of Flavonoids Content in Fruit of Okra (Abelmoschus escullentus L. Moench) from Magelang Central Java Indonesia
}

\author{
Saptono Hadi ${ }^{\# *}$, Thu Zar Soe Myint ${ }^{\#}$ \\ "Department of Pharmacy, Faculty of Mathematics and Natural Sciences, Universitas Sebelas Maret, Surakarta, 646222, Indonesia \\ E-mail: "saptono.hadi@staff.uns.ac.id
}

\begin{abstract}
Okra (Abelmoschus escullentus L. Moench) is a vital vegetable crop widely grown in tropical and sub-tropical parts of the world with high medicinal value. its great potential use as a medicinal plant. Okra is rich in protein, unsaturated fatty acids, minerals, free amino acids, as well as bioactive ingredients, such as flavonoids, alkaloids, steroids, terpenoids. Flavonoids are one important bioactive with many biological activities, such as anti-hepatotoxic, anti-inflammatory, and antioxidant. In this work, the optimum extraction conditions and spectrophotometric method for determining the total flavonoid content from the fruit of okra were investigated. The coarse powder of fruits of okra from Magelang Central Java Indonesia was subjected to extraction by the maceration method with different solvents (water, hexane, and ethyl alcohol). Qualitative analysis using a TLC method of flavonoids was performed in optimized systems chloroform : acetone : formic acid (75: $16.5: 8.5 \mathrm{v} / \mathrm{v})$, and visualization by observing on UV lamp (at $\lambda=254$ and $366 \mathrm{~nm}$ ) spraying with reagent ammonia. UV-Vis spectrophotometry analysis for quantification of flavonoid was previously validated in terms of linearity, the limit of detection, the limit of quantification, precision, and accuracy. The quantitative results of the fruits crude extracts of okra revealed the percentage yield of the flavonoids at the level of $4.41 \mathrm{mg} / \mathrm{g}$ ethanolic extract, which was significantly higher than that of the other extracts. The findings of the present study suggest that the okra fruit extracts have significant amounts of total flavonoid with potential applications in biomedical and pharmaceutical fields.
\end{abstract}

Keywords_- Okra; flavonoids; TLC; UV-Vis spectrophotometry.

\section{INTRODUCTION}

Indonesia is one of the richest biodiversity countries in the world. Okra (Abelmoschus esculentus L. Moench) is one indigenous Indonesian vegetable and also found in other tropical and sub-tropical countries. Okra belongs to an annual herb of Malibaceae and is known by various local names in different parts of the world. e.g., bendi (Indonesia), lady's fingers (Europe), goat angle (China), green ginseng (Japan), etc. Okra is currently planted in India, Turkey, West Africa, and other countries. India is a significant okra producing country, contribute $70 \%$ of the world's total production. It is reported 3.5 million tons of okra is assembled from more than 350,000 hectares of land [1].

Okra has received attention in recent years for its high potential use as a medicinal plant. It is reported that okra is particularly rich in protein, unsaturated fatty acids, minerals, free amino acids, as well as bioactive ingredients, such as flavonoids, alkaloids, steroids, terpenoids, etc. [2], [3].

Flavonoids (Fig.1) are a group of polyphenolic compounds that are widely distributed throughout the plant kingdom, and more than 4000 varieties of flavonoids have been identified and grouped according to their molecular structure Flavonoids exhibit several biological activities, such as anti-hepatotoxic, anti-inflammatory, anti-ulcer, and anti-bacterial and anti-viral activity. Flavonoids are recognized as phytoestrogens because of their structural resemblance to the estrogen in the human body [4]. Moreover, flavonoids play a significant role in the scavenging of free radicals and antioxidants and inhibition of cancer cell growth. For example, quercetin (Fig. 1) inhibits the oxidation of the lipid peroxidation process, reduce cell carcinogenesis [5].<smiles>O=c1cc(-c2ccccc2)oc2ccccc12</smiles><smiles>O=c1c(O)c(-c2ccc(O)c(O)c2)oc2cc(O)cc(O)c12</smiles>

Fig. 1 Basic structure of flavonoid (A); Structure of quercetin (B) 
The data of flavonoids content was fundamental to further utilization of okra, particularly in the field of food and medicine. In previous studies, it was reported that okra fruit juice exhibit a significant effect in lowering cholesterol level in mice. Hamiduzzaman and Sarkar (2014) said that methanol extract okra fruit has antioxidant, antimicrobial, and hypoglycemic activity [6]. Research conducted by Cahyana et al. (2017) found the antioxidant and antidiabetic activity of okra [7].

Moreover, okra has high nutritional importance and contains a considerable proportion of fibers. It is reported that soluble fiber in the form of gums and pectins is the dominant constituent in okra, which has beneficial effects on reducing risk factors for heart disease and lowering the level of serum cholesterol. The other component is insoluble fiber, which is useful for maintaining intestinal tract health [8]. These fibers also give advantage for lowering blood sugar levels by reducing sugar uptake through the intestines which is beneficial for diabetic patients [9].

According to Sudarto and Yudo (1991), okra plants have been planted in Indonesia since 1877, mainly in West Borneo. Okra generally an annual plant. It fibers by seeds and has a cropping duration of 90-100 days. The stem is strong, upright and branched. Its height varies between 0.5 4.0 meters. The okra plants will usually grow the first flower two months after planting. The fruit has capsule-shaped and after flowering, especially 4-6 days after pollination, and at this stage, the fruit is most often picked for consumption. This plant has long been cultivated by farmers as vegetables, which are especially preferred for daily family needs and sold as a commercial product to supermarkets, restaurants, hotels, etc., thus brings excellent profits to farmers. The fruits are usually harvested when immature and before become very fibrous. The fruit contains a lot of mucus so are consumed as vegetables and as soup [8].

However, preliminary phytochemical studies of okra, particularly those plant cultivated in Indonesia, is still limited. Hence, the primary purpose of the present study was the phytochemical investigation of indigenous green okra fruit (Abelmoschus esculentus L. Moench) from Magelang Central Java Indonesia, particularly its flavonoids content. The results of this study are expected to provide scientific information about green okra fruit (Abelmoschus esculentus L. Moench) as a source of flavonoid compounds, thus facilitating further research of the activity and application of flavonoids in the pharmaceutical field.

\section{MATERIAL AND METHOD}

\section{A. Collection of plant sample}

The fresh mature, healthy fruits of Abelmoschus esculentus L. Moench were collected from the local farmland of the District of Magelang at Central Java, Indonesia, which is located on a medium elevation (5001100 masl) and has temperature ranges from $18-32{ }^{\circ} \mathrm{C}$. The sample was selected carefully to avoid unrepresentative sample chemical composition.

The collected plant samples were botanically identified and confirmed by the Department of Biology, Faculty of Mathematics and Natural Sciences, Universitas Sebelas
Maret, Surakarta. Okra belongs to the family Malvaceae and genus Abelmoschus.

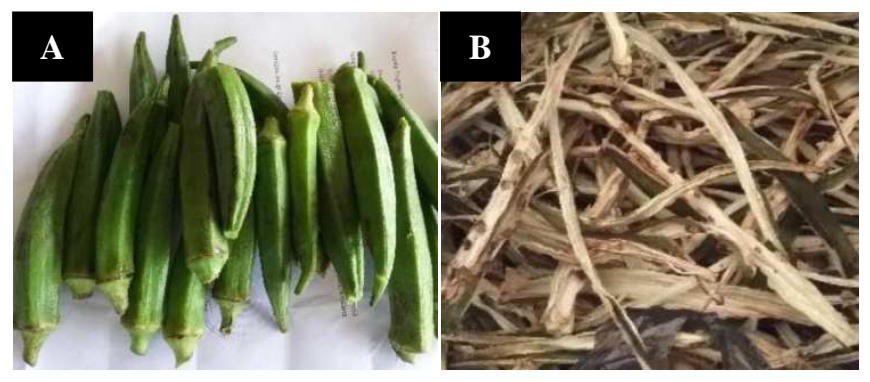

Fig. 2 Green okra fruit (Abelmoschus esculentus L. Moench): A. Fresh fruit; B. Dried fruit by oven drying

\section{B. Preparation of the extracts}

The collected okra fruit samples $(2 \mathrm{~kg})$ were washed by running water, cut into small pieces, then dried in an oven at $55^{\circ} \mathrm{C}$ for $15 \mathrm{~h}$. A total of $135 \mathrm{~g}$ of dry, coarse powder of okra was obtained. The dried powder fiber subjected to extraction by the maceration method by solvents with different polarities: aquadest, ethyl alcohol, and n-hexane. In this step, a total of $45 \mathrm{~g}$ of dried powder of okra was weighed and put in a maceration container, and then $450 \mathrm{~mL}$ solvent was added until all samples are completely submerged by the solvent. Maceration was run at room temperature and was protected from light for $3 \times 24 \mathrm{~h}$. Extraction is filtered to separate the filtrate from the residue. Remaceration of waste was carried out with the same volume of solvent. The filtrate was filtered through No. 1 Whatman filter paper and was then concentrated to extracts by vacuum rotary evaporator. The extract was evaporated again using a water bath at $50^{\circ} \mathrm{C}$ until thick extract is obtained.

\section{Stock solutions and calibration standards}

Standard stock solutions of flavonoids were prepared by dissolving the quercetin standard (Sigma Aldrich, Germany) in ethanol p.a., obtaining concentrations of $100 \mathrm{mg} / \mathrm{mL}$. Stock solutions were stored in a refrigerator at $4{ }^{\circ} \mathrm{C}$.

Calibration standards were prepared at eight levels, ranging from 2 to $20 \mathrm{mg} / \mathrm{mL}$, by dilution of the stock solutions with ethanol p.a. Aliquots of all measures were stored in a refrigerator at $4{ }^{\circ} \mathrm{C}$ until further use.

\section{Qualitative analysis}

The extracts were subjected to qualitative analysis by thin-layer chromatography (TLC) on silica gel (GF; $5 \times 10 \mathrm{~cm})$ using optimized solvents systems and visualized using UV lamp (at $\lambda=254$ and $366 \mathrm{~nm}$ ) after spraying with reagent ammonia. Flavonoids were identified based on the standard retention factor $\left(\mathrm{R}_{\mathrm{f}}\right)$ values matched with the standard.

\section{Method validation}

In this study, the method was validated for parameters of linearity, accuracy, precision, and Limit of Detection (LOD) and Limit of Quantification (LOQ).

The precision of the method was tested as repeatability (intraday) and intermediate precision (interday). The intermediate precision test was conducted using the same equipment and solvents on three consecutive days. The 
precision test was performed at 3 different concentration levels ( $\mathrm{n}=6$ determinations) in three days generating 18 replicates ( $\mathrm{n}=18$ determinations). The accuracy was stated as the relative standard deviation value (\% RSD) to determine variations of the results (Equation 1).

$$
\mathrm{RSD}=\left(\frac{\mathrm{SD}}{\mathrm{Mean}}\right) \times 100
$$

where RSD is the relative standard deviation expressed in percent, SD is the standard deviation. The repeatability (same day precision, intraday) and intermediate precision (interday) should not exceed 5\%, according to the ICH guidelines.

The accuracy was determined by the recovery test, by adding known amounts of a flavonoids reference substance to the samples at three different concentration levels. Efficiency was calculated according to Equation 2,

$$
\% \mathbb{R}=\left(\frac{C_{A}}{C_{T}}\right) \times 100
$$

where $\% \mathrm{R}$ is the accuracy based on the analyte recovery from the sample matrices spiked with quercetin standard, $\mathrm{C}_{\mathrm{A}}$ is the mean obtained concentration, and $\mathrm{C}_{\mathrm{T}}$ is the theoretical concentration. This study was performed at three different concentration levels $(n=3$ determinations). Accuracy should be within the range of 95-105\% (AOAC, 1998).

LOD and LOQ were measured by the calibration curve method. The detection limit (LOD) is the lowest amount of analyte that could be detected in the sample. Further, the quantification limit (LOQ) is the smallest amount of analyte in the sample, which could be determined by precision and accuracy (Equations 3 and 4) using the data from the three curves obtained in the linearity analysis.

$$
\begin{aligned}
& \text { LOD }=\frac{\text { SD } \times 3.3}{\text { Slope }} \\
& L O Q=\frac{\text { SD } \times 10}{\text { Slope }}
\end{aligned}
$$

where SD is the standard deviation of the y-intercept of three calibration curves, and $\mathrm{S}$ is the mean of the slope of the three calibration curves.

\section{Determination of the maximum wavelength}

The maximum wavelength was determined by preparing a $10 \mathrm{mg} / \mathrm{mL}$ quercetin standard in ethanol p.a. A scan from 200 to $400 \mathrm{~nm}$ was further performed to determine the maximum wavelength $\left(\lambda_{\text {máx }}\right)$ using a UV-Vis Genesys $10 \mathrm{~S}$ (Thermo Scientific) spectrophotometer. An ethanol p.a. was prepared as a blank solution. The wavelength that produces maximum absorption is used for the analysis.

\section{E. Determination of flavonoids by spectroscopy $U V$-Vis}

The flavonoids concentrations were determined by using UV spectrophotometry, and the flavonoids concentrations were calculated using an external calibration curve, prepared by standard quercetin solutions.
A total of $1 \mathrm{~g}$ extract was quantitatively weighed and dissolved in $10 \mathrm{~mL}$ ethanol p.a to produce a concentration of $0.1 \mathrm{~g} / \mathrm{mL}$. The absorbance of each sample solution was measured using a UV-Vis spectrophotometer at an optimum wavelength of $493 \mathrm{~nm}$. Measurements were performed at three replication.

\section{RESULTS AND DISCUSSION}

\section{A. Performance of extraction method}

Extraction was performed using the maceration method. The principle is to extract active compounds that can dissolve in solvents based on the level of the polarity of each solvent. This method is based on soaking the sample in the solvent so that the solvent will penetrate the cell wall and enter the cell cavity containing the active compounds. The compound will dissolve in the appropriate solvent because of the difference in concentration between the active substance in the cell and outside the battery so that the adjacent solution is pushed out. This process will continue until the balance of the concentration gradient between the solution outside with those in cells is obtained.

In this study, three solvents with different polarity were used for maceration, that is distilled aquadest, ethyl alcohol, and n-hexane. Rendemen and organoleptic characteristics of the obtained extract are presented in the following Table I.

TABLE I

RENDEMEN AND CHARACTERISTIC OF EXTRACT IN DIFFERENT FRACTIONS

\begin{tabular}{|l|c|c|c|}
\hline \multirow{2}{*}{ Parameters } & \multicolumn{3}{|c|}{ Extract } \\
\cline { 2 - 4 } & Aquadest & Ethanol & n-hexane \\
\hline Weight [g] & 11.57 & 5.87 & 0.85 \\
\hline Rendemen [\%] & 25.70 & 13.00 & 1.90 \\
\hline Texture & viscous & viscous & liquid \\
\hline Colour & $\begin{array}{c}\text { blackish } \\
\text { brown }\end{array}$ & brown & light yellow \\
\hline Odour & distingtive & distingtive & distingtive \\
\hline
\end{tabular}

\section{B. Results of qualitative test}

The advantage of TLC for identification is that method is easy to use for mixture separation, relatively fast, and simple techniques. TLC is used to find the best eluent from several eluents that are good at separating flavonoid compounds. A good eluent is an eluent that produces a large number of compounds characterized by the appearance of spots. The spots formed are not tailed, and the distance between the spots from one another is evident. The use of several eluents is expected to be able to separate the flavonoids contained in okra fruit extract.

The choice of mobile phase for TLC is based on the polarity of the compounds to be identified. Usually, the mobile step used is a mixture of several organic solvents because the elution can be adjusted so that the separation can be optimal. In this study, the variation of eluent used was a mixture of BAW or n-butanol: acetic acid: water (9:2:6), a combination of BAW (4:1:5), and a mix of chloroform: 
acetone: formic acid (75:16.5:8.5). Observation of spots was carried out under UV light at wavelengths of 254 and 366 $\mathrm{nm}$ to reveal the color of separation at the TLC plate.

From the results of the standard mobile phase optimization flavonoid with a mixture of BAW (9:2:6), BAW (4:1:5), and a combination of chloroform: acetone: formic acid (75:16.5:8.5) yielding an $R_{f}$ value of $0.97,0.94$ and 0.37 . These results indicate that a mixture of chloroform : acetone : formic acid (75:16.5:8.5) is the best mobile phase system, as the $R_{\mathrm{f}}$ value lies in the acceptable range, which is $0.3-0.8$. Based on solvent composition, the mobile phase is semipolar so that it can separate flavonoid compounds, which are also semipolar. Mobile phase optimization is presented in Fig. 3.

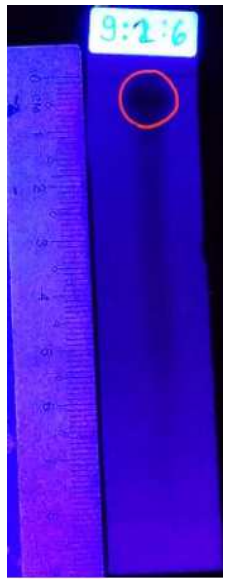

A

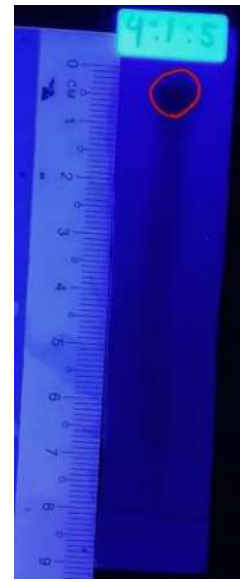

B

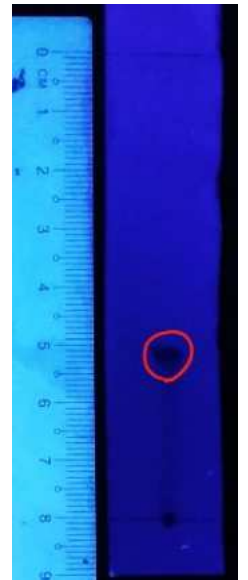

C
Fig. 3 Mobile phase optimization: A. BAW (9:2:6), B. BAW (4:1:5) and C. Chloroform: acetone: formic acid (75:16.5:8.5), yielding an $\mathrm{R}_{\mathrm{f}}$ value of $0.97,0.94$ and 0.37 respectively

From the results of the qualitative analysis using TLC with the mobile phase of chloroform : acetone : formic acid $(75: 16,5: 8,5)(\mathrm{v} / \mathrm{v})$ showing dark brown spots (after being steamed with ammonia). $R_{f}$ values of aquadest extract, ethyl alcohol extract, and n-hexane extract of okra fruit are shown in Fig. 4 and Table II.

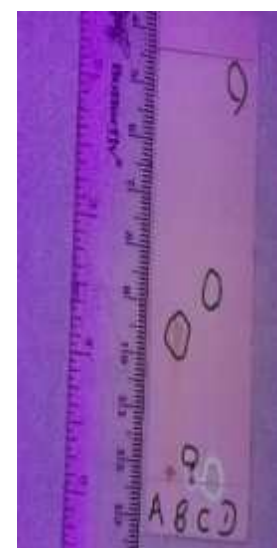

I

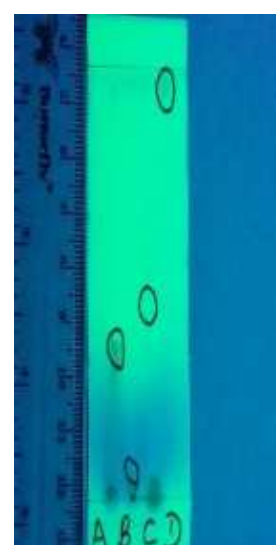

II
Fig. 4. TLC separation profile with mobile phase chloroform: acetone formic acid $(75: 16.5: 8.5)(\mathrm{v} / \mathrm{v})$ : A. quercetin standard, B. aquadest extract, C. ethyl alcohol extract, and D. n-heksan extract viewed under visible light (I) and UV light (II)
TABLE II

CONTENTS OF FLAVONOIDS (AS QUERCETIN) IN DIFFERENT FRACTIONS

\begin{tabular}{|l|c|c|}
\hline Extract & $\begin{array}{c}\text { Spot distance } \\
{[\mathbf{c m}]}\end{array}$ & $\mathbf{R}_{\mathbf{f}}$ \\
\hline Aquadest & 0.5 & 0,062 \\
\hline n-hexane & 7.5 & 0,975 \\
\hline Ethyl alcohol & 3.3 & 0,412 \\
\hline Standard of quercetin & 3.0 & 0,375 \\
\hline
\end{tabular}

From Fig. 4, flavanoids showed their presence in ethyl alcohol extract with $R_{f}$ values of detected spots were closest to the standard $R_{f}$ values, which were 0.412 and 0.375 respectively. From the $\mathrm{R}_{\mathrm{f}}$ value data, there was a shift in the value of the $R_{f}$ of the sample by $8.9 \%$ when compared to the standard. This is probably due to the extract that is bottled in the form of an extract that has not been purified, causing an effect of the matrix on the value of $R_{f}$. This is also shown in a study conducted by Sunyoto et al. (2012) on the isolation and identification of red galangal rhizome flavonoids, where there is a shift in the value of $\mathrm{R}_{\mathrm{f}}$ between quercetin standards and samples of $8.8 \%$.

The spots identified as quercetin appeared intensively on ethyl alcohol extract, while aquadest extract and n-hexane extract were not intensive enough to provide the spots. In a study conducted by Satolom et al. (2015), the analysis of flavonoids in Yaki areca seeds (Areca vestiaria Giseke) showed that quercetin could be extracted in n-hexane and aquadest at much lower levels than methanol and ethyl acetate extracts [10]. Thus, in this study, it was suspected that quercetin was also extracted in aquadest and n-hexane extract even at low levels. Therefore, a further quantitative test was carried out on all three extracts.

\section{Measurement of optimum wavelength}

The determination of the maximum wavelength aims to set the optimum condition of the UV-Vis spectrophotometer in detecting the absorption of a substance to be analyzed. Measurements at the maximum wavelength are preferable because it produces maximum sensitivity. UV-Vis scanning of the quercetin standard can be seen in Fig. 5.

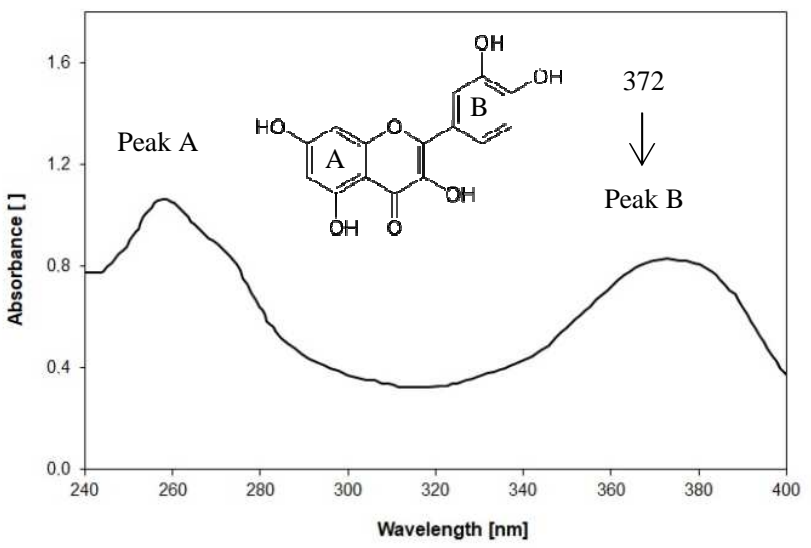

Fig. 5 UV Spectra of quercetin 
From the result, the selected maximum wavelength is 373 nm. This wavelength was chosen because it was in accordance with the research conducted by Chaudhari et al. (2014) found that the maximum wavelength of quercetin analyzed using ethanol solvents produced maximum absorption peaks at a wavelength of $372 \mathrm{~nm}$ [11]. Therefore, the current result is still at an acceptable range of $\pm 2 \mathrm{~nm}$ of the reference wavelength.

\section{Method validation of the spectroscopic method}

Validation of the analysis method needs to be done to prove that a method can provide accurate results and meet requirements. In this study, the validation test was performed on the parameters of linearity, accuracy, precision, Limit of Detection (LOD), and Limit of Quantification (LOQ).

1) Standard curve: The linear regression equation was calculated from the calibration curve. The linear regression equation $\mathrm{y}=0.0854 \mathrm{x}-0.0166$, where the correlation coefficient is $r=0.9973$, indicating good linearity on the $0.08-1.00 \mathrm{mg} / \mathrm{mL}$ range (Fig. 6).

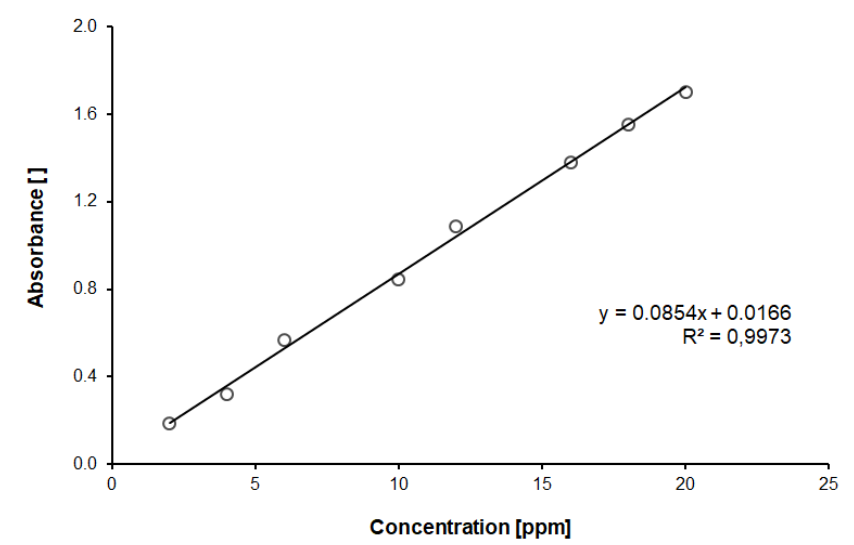

Fig. 6 Calibration curve for quercetin standard.

2) Precision: The data shows that $\%$ RSD is less than 3.7\%; this result meets the precision requirements (AOAC, 1998). Variations that appear on the results can be caused by the presence of various factors that are difficult to control, such as interference and different conditions for each measurement.

TABLE III

THE PRECISION OF THE METHOD

\begin{tabular}{|c|c|c|}
\hline Spiking level & Repeatability $^{\text {a) }}$ & $\begin{array}{c}\text { Intermediate } \\
\text { precision }\end{array}$ \\
\hline Low & 0.539 & 1.309 \\
\hline Middle & 0.488 & 0.875 \\
\hline High & 0.235 & 0.715 \\
\hline
\end{tabular} $\begin{aligned} & \text { a) RSD of six determinations; }{ }^{b} \text { RSD of six determinations on three } \\
& \text { consecutive days }\end{aligned}$

3) Accuracy: Result obtained for the recovery test of quercetin at three different spiking levels were $100.43 \%$. The value of $\%$ recovery lies in the acceptable recovery range of $95-105 \%$ set by AOAC. The accuracy of an analytical method may be determined by any error that causes \% recovery is not exactly $100 \%$, such as systematic errors from equipment.

TABLE IV

RECOVERY OF THE METHOD

\begin{tabular}{|c|c|c|c|}
\hline $\begin{array}{c}\text { Spiking level } \\
{[\mathrm{ppm}]}\end{array}$ & $\begin{array}{c}\text { Improvemen } \\
t[\%]\end{array}$ & $\begin{array}{c}\text { Mean } \\
{[\%]}\end{array}$ & SD \\
\hline 4 & 100.35 & \multirow{3}{*}{100.43} & \multirow{3}{*}{0.09} \\
\hline 5 & 100.43 & & \\
\hline 6 & 100.52 & & \\
\hline
\end{tabular}

4) Detection Limit: The method of determining detection limits used is the calculation of linear equations $\mathrm{y}=\mathrm{bx}+\mathrm{a}$. The LOD and LOQ values can be calculated based on the standard deviation and standard slope obtained. From the statistical calculation using the standard curve equation derived from the table, the LOD $(\mathrm{ppm})=1.614 \pm 0.317$ and LOQ $(\mathrm{ppm})=4.892 \pm 0.961$.

TABLE IV

DATA OF LOD AND LOQ

\begin{tabular}{|c|c|c|}
\hline Parameters & $\begin{array}{c}\text { Mean }^{\text {a) }} \\
{[\mathbf{p p m}]}\end{array}$ & $\begin{array}{c}\text { SD } \\
{[\mathbf{p p m}]}\end{array}$ \\
\hline LOD & 1.614 & 0.317 \\
\hline LOQ & 4.892 & 0.961 \\
\hline
\end{tabular}

\section{E. Determination of flavonoids contents}

The flavonoid level was calculated as mg quercetin/g extract. The results of the calculation can be seen in Table V.

TABLE V

CONTENTS OF FlaVONOIDS (AS QUERCETIN) IN DIFFERENT FRACTIONS

\begin{tabular}{|l|c|c|c|}
\hline Extract & $\begin{array}{c}\text { Concentration }^{\text {a) }} \\
{[\mathbf{m g} / \mathbf{g}]}\end{array}$ & SD & RSD\% \\
\hline Ethyl-alcohol & 4.40 & 0.07 & 1.59 \\
\hline Aquadest & 0.62 & 0.01 & 1.21 \\
\hline n-Hexan & 0.13 & 0.00 & 0,11 \\
\hline
\end{tabular}

The study showed that flavonoid in the fruit of okra from Magelang Indonesia was relatively high, at a level of $4.41 \pm$ $0.07 \mathrm{mg}$ quercetin/g in ethanol extract. This flavonoid level was much higher than that was found in aquadest and nhexane extract. The reason ethyl alcohol has two sides groups consisting of polar $(\mathrm{OH})$ and nonpolar $\left(\mathrm{CH}_{2} \mathrm{CH}\right)$ groups so that it can extract semipolar flavonoids. Also, flavonoid aglycones such as isoflavones, flavones, and flavones, and thermetoxylated flavonols tend to be more soluble in semipolar solvents such as ether, chloroform, ethyl acetate, and n-butanol, whereas flavonoids glycosides are more soluble in more polar solvents such as water. For non-polar n-hexane solvents, it is not very useful to dissolve flavonoids. So that from these results, it can be shown that in ethanol extract, $96 \%$ of the green okra fruit contains a lot of flavonoids, aglycones, or flavonoids, which are not bound to sugar. 
In comparison to previous studies, the red okra fruit skin from Jakarta Indonesia contains flavonoid equal to $0.42 \mathrm{mg}$ quercetin/g [12]. Other research reported that flavonoid content in green okra fruit from Bandung Indonesia was 0.07 $\pm 0.36 \mathrm{mg}$ quercetin/g [7]. The study by Khomsug et al. (2010), shows that total flavonoid content (TFC) in okra from Thailand was equal to $1075 \pm 0.02$ and $1424.8 \pm 0.02$ $\mathrm{mg} / \mathrm{g}$ in pods and seeds, respectively [13]. Whereas Adelakun et al. (2009) obtained $32.54 \pm 32.42 \mathrm{mg} / \mathrm{g}$ for blanched seeds, $48.3 \mathrm{mg} / \mathrm{g}$ for raw seeds, and $51.28 \mathrm{mg} / \mathrm{g}$ for seeds slumped in water [14] whereas research conducted by Ahiakpa et al. (2013) using the colorimetric method showed that TFC in okra fruit from Ghana was $2288.20 \pm 27.75 \mathrm{mg}$ quercetin/g in ethanol extract [15].

These results showed differences in flavonoid content in okra plants originating from different areas. This study also indicates the indigenous okra fruit from Indonesia as a potential source of flavonoids.

\section{CONCLUSIONS}

The results of measurements of flavonoid levels were quantitatively used UV-Vis spectrophotometry method contained in ethyl alcohol extract at $4.40 \pm 0.07 \mathrm{mg}$ quercetin/g, while in aquadest extract and n-hexane extract was much lower, which was $0.62 \pm 0.01$ and $0.13 \pm 0,00 \mathrm{mg}$ quercetin/g extract, respectively. This research shows the indigenous green okra fruit from Indonesia as a potential source of flavonoids.

\section{ACKNOWLEDGMENT}

The authors would like to thank the Indonesian Directorate General of Higher Education (DIKTI) for funding the publication of this paper

\section{REFERENCES}

[1] P. Singh, V. K. Chauhan, B. Tiwari, S. S. S. Chauhan, S. B. Simon, and A. B. Abidi, "An overview on okra (Abelmoschus esculentus) and it's importance as a nutritive vegetable in the world," Int. J. Pharm. Biol. Sci., vol. 4, no. 2, pp. 227-233, 2014.

[2] L. H. Yao et al., "Flavonoids in food and their health benefits.," Plant Foods Hum. Nutr., vol. 59, no. 3, pp. 113-22, 2004.
[3] A. Roy, S. L. Shrivastava, and S. M. Mandal, "Functional properties of Okra Abelmoschus esculentus L. (Moench): traditional claims and scientific evidences," Plant Sci. Today, vol. 1, no. 3, pp. 121-130, 2014.

[4] A. N. Panche, A. D. Diwan, and S. R. Chandra, "Flavonoids: An overview," J. Nutr. Sci., vol. 5, no. 47, pp. 1-15, 2016.

[5] A. V. Anand David, R. Arulmoli, and S. Parasuraman, "Overviews of Biological Importance of Quercetin: A Bioactive Flavonoid.," Pharmacogn. Rev., vol. 10, no. 20, pp. 84-89, 2016.

[6] M. Hamiduzzaman and A. S. M. M. Sarkar, "Evaluation of biological activities of Abelmoschus esculentus (Malvaceae)," Int. J. Curr. Sci., 2014.

[7] H. A. Cahyana, N. Kam, and Ellyn, "Study on the stability of antioxidant and anti $\alpha$-glucosidase activities using soaking treatment in okra (Abelmoschus esculentus L.) mucilage extraction," Chem. Int., vol. 3, no. 3, pp. 202-211, 2017.

[8] H. F. Gemede, N. Ratta, H. G.D., A. Z. Woldegiorgis, and F. Beneye, "Nutritional quality and health benefit of okra (Abelmoschus Esculentus): A review," Glob. J. Med. Res., vol. 14, no. 5, pp. 1-10, 2014.

[9] D. G. Romatua Aruan, T. Barus, G. Haro, R. Siburian, and P. Simanjuntak, "Phytochemical Screening and Antidiabetic Activity of N-Hexane, Ethyl Acetate and Water Extract from Durian Leaves (Durio Zibethinus L.)," Orient. J. Chem., vol. 35, no. 1, pp. 487-490, 2019.

[10] C. C. Satolom, M. R. J. Runtuwene, and J. Abidjulu, "Isolasi Senyawa Flavonoid Pada Biji Pinang Yaki (Areca vestiaria Giseke)," J. MIPA, vol. 4, no. 1, p. 40, 2015.

[11] S. Chaudhari, J. V. Bangar, G. K. Akuskar, and M. P. Ratnaparkhi, "Development and Validation of UV Spectrophotometric Method for Simultaneous Estimation of Rutin and Quercetin in Niosome Formulation," Der Pharm. Lett., vol. 6, no. 3, pp. 271-276, 2014.

[12] N. Lisnawati, I. A. Handayani, and N. Fajrianti, "Analisis flavonoid dari ekstrak etanol 96\% kulit buah okra merah (Abelmoschus esculentus L. Moench) secara kromatografi lapis tipis dan spektrofotometri UV-Vis," J. Ilm. Ibnu Sina, vol. 1, no. 1, pp. 105$112,2016$.

[13] P. Khomsug, W. Thongjaroe, N. Pakdeenaro, M. Suttajit, and P. Chantirati, "Antioxidative Activities and Phenolic Content of Extracts from Okra (Abelmoschus esculentus L.)," Res. J. Biol. Sci., vol. 5, no. 4, pp. 310-313, 2010.

[14] O. E. Adelakun, O. J. Oyelade, B. I. O. Ade-Omowaye, I. A. Adeyemi, and M. Van de Venter, "Chemical composition and the antioxidative properties of Nigerian Okra Seed (Abelmoschus esculentus Moench) Flour.," Food Chem. Toxicol., vol. 47, no. 6, pp. 1123-6, 2009.

[15] J. K. Ahiakpa et al., "Total flavonoid, phenolic contents and antioxidant scavenging activity in 25 accessions of okra (Abelmoschus spp L.)," African J. Food Sci. Technol., vol. 4, no. 5, pp. 129-135, 2013. 